\title{
Phenothiazine-induced dystonia associated with an increase in serum creatine phosphokinase
}

\author{
W. Y. LUI \\ Department of Paediatrics, University of Hong Kong
}

SUMMARY A transient but considerable rise in serum creatine phosphokinase (CPK) levels occurred in six boys aged between 8 and 11 years and suffering from phenothiazine-induced dystonia. In one boy (Case 4), after the CPK level had returned to normal after withdrawal of the drug, its reintroduction orally at lower dosage caused a slight increase in the level of CPK in the absence of any recurrence of the dystonia.

Muscle dystonia associated with administration of certain phenothiazine derivatives is well known (Goldsmith, 1959; Ayd, 1961). Laboratory investigations in such patients have been normal. In a survey of serum creatine phosphokinase (CPK) levels in Chinese children, it was noticed that there was a transient increase in CPK levels in some children who suffered drug-induced dystonia.

\section{Material and methods}

Six Chinese boys aged between 8 and 11 years were admitted for dystonia into this hospital. Four had received phenothiazine derivatives orally. A single IM injection of prochlorperazine had been given in 2 other boys. None had a disease known to be associated with raised levels of CPK. Apart from the 2 boys who each had received one IM injection of prochlorperazine, none had had any medical treatment known to cause an increase in CPK. Their clinical details are given in the Table. Between 24 and 48 hours after oral or IM administration of the drug, the child generally developed painful spasms of facial, neck, and sometimes limb muscles. The head and sometimes the eyes were deviated involuntarily to one direction. The mouth was open, or spasmodic attacks of trismus occurred. One or more extremities, and at times the whole body, might be held spasmodically in a bizarre posture. The child was invariably conscious but could not speak as a result of muscle spasms.

IV diphenhydramine was given to 4 boys after being in hospital; the other 2 received no treatment. Dystonia subsided within 36 hours in all 6 boys, but pain in affected muscles persisted for 2 to 7 days.

Serum was collected immediately after admission and then serially. CPK was assayed immediately after collection or after storage in dark containers at $-20^{\circ} \mathrm{C}$ for not more than 5 days. A colorimetric method using Sigma kit 661-PB was used. The normal range with this method in Chinese boys of this age group is 2-17 Sigma units/ml.

Table Clinical details and serum CPK levels

\begin{tabular}{|c|c|c|c|c|c|c|c|}
\hline \multirow{2}{*}{$\begin{array}{l}\text { Age } \\
\text { (years) }\end{array}$} & \multirow[t]{2}{*}{ Drug responsible } & \multicolumn{2}{|l|}{ Dystonia } & \multirow[t]{2}{*}{ Features } & \multirow{2}{*}{$\begin{array}{l}\text { Duration of } \\
\text { muscle pain } \\
(\text { days })\end{array}$} & \multirow{2}{*}{$\begin{array}{l}\text { Peak serum CPK } \\
\text { level* (Sigma } \\
\text { units } / m l)\end{array}$} & \multirow{2}{*}{$\begin{array}{l}\text { Duration of raised } \\
\text { serum CPK }\end{array}$} \\
\hline & & $\begin{array}{l}\text { Onset } \\
\text { (hours) }\end{array}$ & $\begin{array}{l}\text { Duration } \\
\text { (hours) }\end{array}$ & & & & \\
\hline $9 \frac{1}{9}$ & $\begin{array}{l}\text { Prochlorperazine } \\
5 \mathrm{mg} \text { oral } \times 2 \text { for } \\
\text { vomiting }\end{array}$ & Within 24 & 24 & $\begin{array}{l}\text { Torsion head and } \\
\text { neck }\end{array}$ & 4 & 104 & Days 2-6 \\
\hline 11 & $\begin{array}{l}\text { Perphenazine } 2 \mathrm{mg} \\
\text { oral } \times 3 \text { for vomiting }\end{array}$ & Within 24 & 36 & $\begin{array}{l}\text { Torsion head and } \\
\text { neck }\end{array}$ & 2 & 84 & Days 2-5 \\
\hline 9 & $\begin{array}{l}\text { Haloperidol } 0.5 \mathrm{mg} \text { oral } \\
\text { for behavioural problem }\end{array}$ & $\begin{array}{l}\text { Within } 24 \\
\text { is }\end{array}$ & 48 & $\begin{array}{l}\text { Torsion head, } \\
\text { oculogyric crisis, } \\
\text { mouth open, } \\
\text { salivation, } \\
\text { sweating }\end{array}$ & 3 & 30 & Days 2-4 \\
\hline 8 & $\begin{array}{l}\text { Haloperidol } 1 \mathrm{mg} \text { oral } \\
\times 3 \text { for behavioural } \\
\text { problems }\end{array}$ & Within 36 & 24 & $\begin{array}{l}\text { Trismus, torsion } \\
\text { head and neck }\end{array}$ & 7 & 74 & $\begin{array}{l}\text { Days 2-6 } \\
11 \text { (see text) }\end{array}$ \\
\hline $9 \frac{1}{2}$ & $\begin{array}{l}\text { Prochlorperazine } 12.5 \mathrm{mg} \\
\text { IM for vomiting }\end{array}$ & Within 24 & 24 & $\begin{array}{l}\text { Torsion head and } \\
\text { neck, rigid limbs }\end{array}$ & 2 & 135 & Days 2-3 \\
\hline 11 & $\begin{array}{l}\text { Prochlorperazine } 12.5 \mathrm{mg} \\
\text { IM for vomiting }\end{array}$ & Within 24 & 24 & $\begin{array}{l}\text { Oculogyric crisis } \\
\text { torsion head and } \\
\text { neck }\end{array}$ & 2 & 97 & Days 1-3 \\
\hline
\end{tabular}

* Normal range 2-17 Sigma units/ml. 


\section{Results}

In all 6 boys, serum CPK was abnormally high, reaching a peak level between 2 and 4 days after the onset of dystonia. Thereafter the levels dropped to normal within a week. The peak levels reached ranged from 30 to 135 Sigma units/ml.

In one 8-year-old boy (Case 4), in whom dystonia had been induced by three oral $1 \mathrm{mg}$ doses of haloperidol given within a day (for psychiatric symptoms), the peak CPK level was 74 Sigma units/ $\mathrm{ml}$. After withdrawal of haloperidol, the level fell to 9 Sigma units $/ \mathrm{ml}$ in a week. Three days after reintroducing the drug at $0.5 \mathrm{mg}$ twice a day, his CPK level rose to 19 Sigma units/ml, but without any recurrence either of muscle pain or dystonia.

\section{Discussion}

Raised levels of serum CPK have been known to be associated with active progressive muscular dystrophy, acute polymyositis, periodic paralysis, repeated intramuscular infections, strenuous exercise, myocardial infarction, and cardiac catheterisation, and also with the immediate newborn period. Although increased levels of CPK have been reported in patients with Wilson's disease who had marked rigidity (Okinaka et al., 1964), its increase in patients suffering from drug-induced dystonia was not reported. With severe muscle dystonia, this enzyme may perhaps be released into the circulation. Previous reports on phenothiazine-induced dystonia found no correlation between the dosage or route of administration of the drug, and the occurrence and severity of dystonia (Goldsmith, 1959). It is notable however that in our Case 4 the CPK level rose again on reintroducing the drug at a lower dosage but did not cause dystonia or muscle pain. This raises the possibility that the offending drug at a lower dosage may lead to subclinical disturbances of muscle function.

\section{References}

Ayd, F. J., Jr (1961). A survey of drug-induced extrapyramidal reactions. Journal of the American Medical Association, 175, 1054-1060.

Goldsmith, R. W. (1959). Toxicity of phenothiazine compounds. Pediatrics, 23, 1015-1C16.

Okinaka, S., Sugita, H., Momoi, H., Toyokura, Y., Watanabe, T., Ebashi, F., and Ebashi, S. (1964). Cysteinestimulated serum creatine kinase in health and disease. Journal of Laboratory and Clinical Medicine, 64, 299-305.

Correspondence to Dr W. Y. Lui, Department of Paediatrics, Queen Mary Hospital, Hong Kong. 